\title{
Penguatan Kapasitas Pelayan Guna Meningkatkan Kesehatan Jasmani dan Mental Jemaat GPM "Silaleinitu" Ditengah Pandemi Covid-19
}

\author{
Andris Noya, Lolita L. Ririhena, Agnes N. Mahakena, Presly G. Siahaya \\ Institut Agama Kristen Negeri Ambon, Jl. Dolog Halong Atas Ambon, Maluku, Indonesia \\ Email: anoya335@gmail.com
}

\begin{abstract}
Abstrak
Pandemi Covid-19 telah mengubah kebiasaan di masyarakat, termasuk sistem operasi dalam bekerja. Dengan mengikuti instruksi pemerintah untuk menghindari perkumpulan massa dan penyebaran virus, setiap instansi dan/atau organisasi mengubah operasional dengan bekerja dari rumah. Hal ini juga berdampak pada pelayanan yang dikerjakan oleh gereja sebagai salah satu lembaga keagamaan yang berada ditengah-tengah masyarakat. Menyikapi hal ini, hendaknya para pelayan sebagai ujung tombak penggerak pelayanan dalam lingkup gereja dibekali guna penguatan kapasitas pelayan, untuk mengoptimalkan potensi yang ada dalam menatalayani umat ditengah situasi pandemic Covid-19. Menyikapi situasi ini, Institut Agama Kristen Negeri (IAKN) Ambon melalui Program Studi Pastoral Konseling menyelenggarakan kegiatan Pengabdian kepada Masyarakat (PkM) yang bertujuan untuk meningkatkan kemampuan kognitif dan psikomotorik para pelayan dalam melayani umat ditengah pandemic Covid-19. Kegiatan sosialisasi dan pelatihan ini mengikutsertakan Majelis Jemaat bersama perangkat pelayan dan Badan Koordinator Pelayanan (Bakopel) pada masing-masing sektor dan unit pelayanan. Kegiatan dilaksanakan dalam dua tahap, yakni tahap sosialisasi pada tanggal 30 September s.d 01 Oktober 2020 dan tahap praktek pada tanggal 27 s.d 28 Oktober 2020. Diakhir kegiatan dilaksanakan evaluasi dengan tujuan untuk mengetahui efektivitas kegiatan PkM yang dilaksanakan. Diungkapkan oleh peserta bahwa kegiatan ini sangat bermanfaat dalam pengembangan kapasitas pelayan gereja dalam menatalayani umat dimasa pandemic.
\end{abstract}

Kata Kunci: Penguatan Kapasitas Pelayan, Kesehatan Jasmani, Mental, Spiritual, Covid-19.

\section{Pendahuluan}

Pandemi Corona Virus 2019 ( COVID-19) merupakan penyakit menular yang disebabkan oleh sindrom pernapasan akut corona virus 2 (SARS-CoV-2). Wabah ini pertama kali diidentifikasi pada Desember 2019 di Wuhan, ibukota provinsi Hubei China, dan sejak itu menyebar secara global, mengakibatkan pandemic corona virus 2019 yang sedang berlangsung (Siahaan, 2020). Menyikapi kondisi ini, pemerintah menerapkan Pembatasan Sosial Berskala Besar (PSBB) demi memutus mata rantai penyebaran virus corona. Langkah ini dipandang efektif karena membantu mencegah penyebaran virus corona baik dari satu orang ke orang lainnya maupun dari satu daerah ke daerah lainnya. Sehingga masyarakat dapat terhindar dari wabah ini (Nasruddin \& Haq, 2020).

Menyikapi peraturan pemerintah terkait PSBB, berbagai kebijakan diambil serta diterapkan pada lingkungan kerja baik itu pemerintahan maupun swasta. Demikian juga dengan berbagai kegiatan yang bersifat pengerahan masa dibatasi, diantaranya pelaksanaan peribadatan untuk semua agama yang ada di Indonesia. Awalnya pembatasan pelaksanaan peribadatan menimbulkan pro dan kontra. Tetap dalam penerapannya, berbagai tokoh dan elemen keagamaan dengan sadar akan bahaya penularan Covid-19, rela tidak mengadakan ibadah pada tempat yang biasanya digunakan. Situasi ini juga terjadi pada gereja-gereja, di mana sejak akhir Maret 2020 tidak lagi melaksanakan ibadah pada gedung gereja. Peribadatan dialihkan secara digital, melalui teknologi live streaming. Tujuannya agar menghambat laju penularan Covid-19 yang dapat terjadi melalui kontak fisik (Dwiraharjo, 2020).

Dalam situasi pandemic, umat (dalam hal ini jemaat) memiliki berbagai persoalan kehidupan. Berbagai persoalan yang muncul diantaranya dari segi ekonomi, persoalan kehidupan keluarga, pendidikan dan pembinaan anak di rumah, serta masalah kesehatan (Buana, 2020). Berbagai 
persoalan yang muncul di tengah-tengah kehidupan jemaat membutuhkan perhatian serta penangangan khusus dari para pelayan. Menyikapi situasi yang ada, Program Studi Pastoral Konseling Institut Agama Kristen Negeri (IAKN) Ambon melakukan kegiatan Pengabdian Kepada Masyarakat (PKM) dalam bentuk penguatan kapasitas pelayan guna menyikapi persoalan yang terjadi di tengah-tengah kehidupan jemaat.

\subsection{Tujuan Kegiatan}

Adapun tujuan diselenggarakan kegiatan ini untuk memberikan pemahaman yang baik dan benar kepada para pelayan tentang pandemic Covid-19, pelatihan layanan konseling dimasa pandemic secara khusus tentang teknik-teknik konseling, serta penguatan kapasitas orangtua terkait pendidikan dalam keluarga dimasa pandemic.

\subsection{Manfaat Kegiatan}

Manfaat yang diharapkan dari kegiatan ini yakni para pelayan yang ada di Jemaat GPM SilaLeinitu memiliki pemahaman yang baik dan benar tentang Corona Virus-19 (Covid-19), para pelayan dan masyarakat dapat menerapkan protocol kesehatan selama masa pandemic, para pelayan mampu menerapkan layanan konseling pada masa pandemic sesuai prosedur yang berlaku, serta mampu menerapkan pola pengasuhan dengan baik dan benar ditengah keluarga dalam masa pandemic Covid-19.

\subsection{Luaran Pengabdian Kepada Masyarakat}

Target Luaran dalam kegiatan pengabdian kepada masyarakat ini, yaitu:

a. Para pelayan dan masyarakat memahami dengan baik dan benar tentang pandemic Covid19.

b. Para pelayan mampu menerapkan layanan konseling dengan baik dan benar dalam masa pandemic Covid-19.

c. Masyarakat dalam hal ini orangtua mampu menerapkan pola pengasuhan yang tepat dalam keluarga selama masa pandemic Covid-19.

\section{Realisasi Kegiatan}

\subsection{Bentuk Kegiatan \& Jadwal, Serta Tempat Kegiatan}

\section{a. Metode Pelaksanaan Kegiatan}

Penguatan kapasitas pelayan guna meningkatkan kesehatan jasmani dan mental di Jemaat GPM Silaleinitu dilaksanakan dengan menggunakan metode ceramah, diskusi dan praktik. Metode ceramah dipakai untuk menjelaskan tentang penerapan protocol kesehatan pada masa pandemic Covid-19, penjelasan teori-teori konseling, dan penjelasan tentang pola pengasuhan selama masa pandemic Covid-19. Metode diskusi digunakan bilamana ada pertanyaan-pertanyaan yang dikemukakan oleh peserta kegiatan kepada fasilitator dan membutuhkan jawaban langsung. Sedangkan metode ketiga yakni praktek digunakan untuk pelatihan proses konseling dan praktek terapi relaksasi. Proses kegiatan dilaksanakan dalam 4 kali pertemua dimana masing-masing pertemuan selama 5 jam. Selama kegiatan, peserta dilengkapi dengan modul pelatihan yang dipakai untuk acuan pelatihan.

\section{b. Waktu Efektif Pelaksanaan Kegiatan}

Kegiatan Pelaksanaan Pengabdian Kepada Masyarakat ini akan dilaksanakan dalam dua tahap. Tahap I yakni tahap sosialisasi yang dilaksanakan pada tanggal 30 September s.d 01 Oktober 2020 dan tahap II yakni tahap pelatihan yang dilaksanakan pada tanggal 27 s.d 28 Oktober 2020 dengan rincian sebagai berikut:

Tabel 1. Jadwal Pelaksanaan

\begin{tabular}{|c|l|c|c|c|c|}
\hline NO & \multicolumn{1}{|c|}{ Kegiatan } & \multicolumn{3}{|c|}{ Jadwal Pelaksanaan Tanggal : } \\
\cline { 4 - 6 } & & $\mathbf{3 0}$ Sept & $\mathbf{0 1}$ Okt & 27 Okt \\
\hline 1 & $\begin{array}{l}\text { Sosialisasi tentang protocol } \\
\text { kesehatan dalam masa pandemic } \\
\text { Covid-19 }\end{array}$ & & & & \\
\hline
\end{tabular}




\begin{tabular}{|c|c|c|c|c|c|}
\hline \multirow{2}{*}{ NO } & \multirow{2}{*}{ Kegiatan } & \multicolumn{4}{|c|}{ Jadwal Pelaksanaan Tanggal : } \\
\hline & & 30 Sept & 01 Okt & 27 Okt & $280 k t$ \\
\hline 2 & $\begin{array}{l}\text { Sosialisasi smart parenting dalam } \\
\text { masa pandemic Covid-19 }\end{array}$ & & & & \\
\hline 3 & Sosialisasi teknik-teknik konseling & & & & \\
\hline 4 & $\begin{array}{l}\text { Sosialisasi tentang memahami } \\
\text { stress pada masa pandemic Covid- } \\
19\end{array}$ & & & & \\
\hline 5 & Pelatihan Teknik-Teknik Konseling & & & & \\
\hline 6 & $\begin{array}{l}\text { Teknik penanganan stress dimasa } \\
\text { pandemic: Relaksasi Otot Progresif }\end{array}$ & & & & \\
\hline 7 & $\begin{array}{l}\text { Evaluasi smart parenting dalam } \\
\text { masa pandemic Covid-19 }\end{array}$ & & & & \\
\hline
\end{tabular}

\section{c. Tempat Kegiatan}

Tempat pelaksanaan pengabdian kepada masyarakat ini di Jemaat GPM Sila-Leinitu yang beralamat di Desa Sila, Kecamatan Nusalaut, Kabupaten Maluku Tengah, Provinsi Maluku 92711.

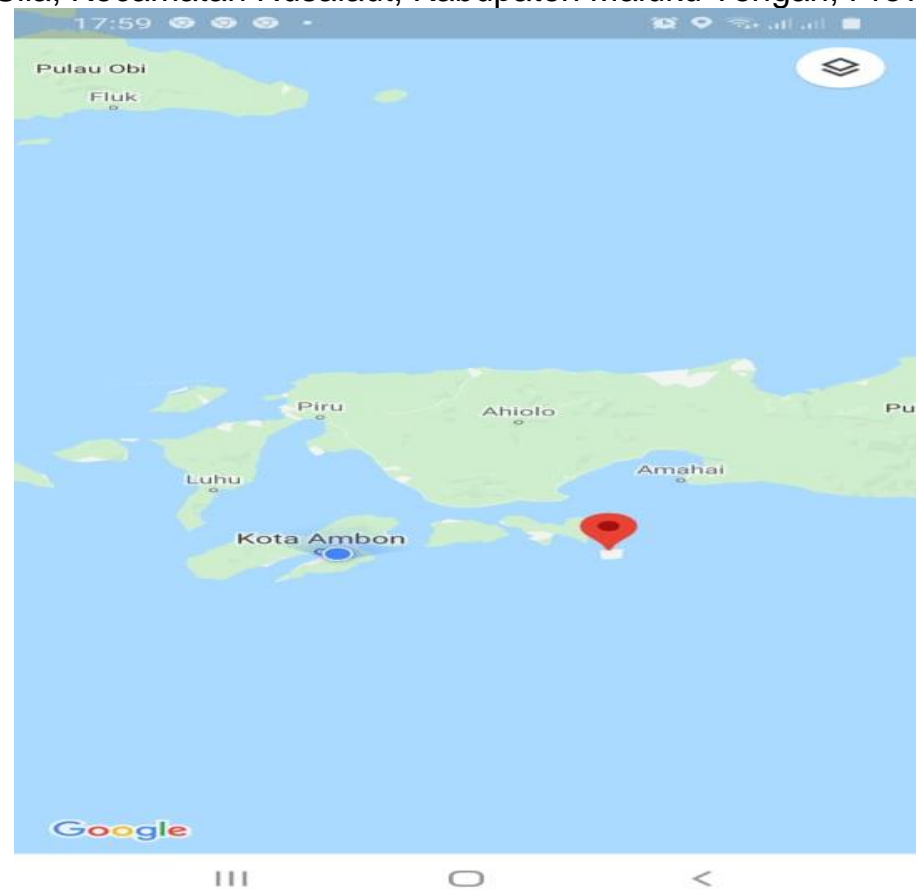

Gambar 1. Maps Lokasi 


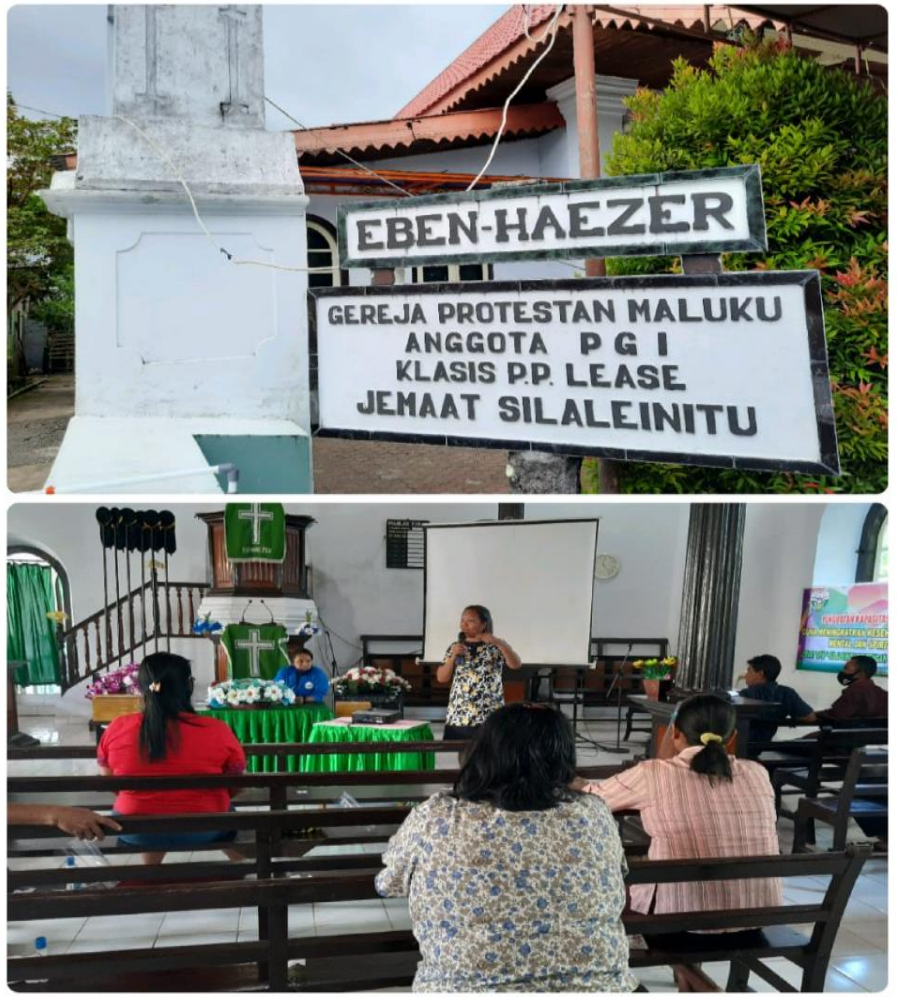

Gambar 2. Lokasi Pengabdian
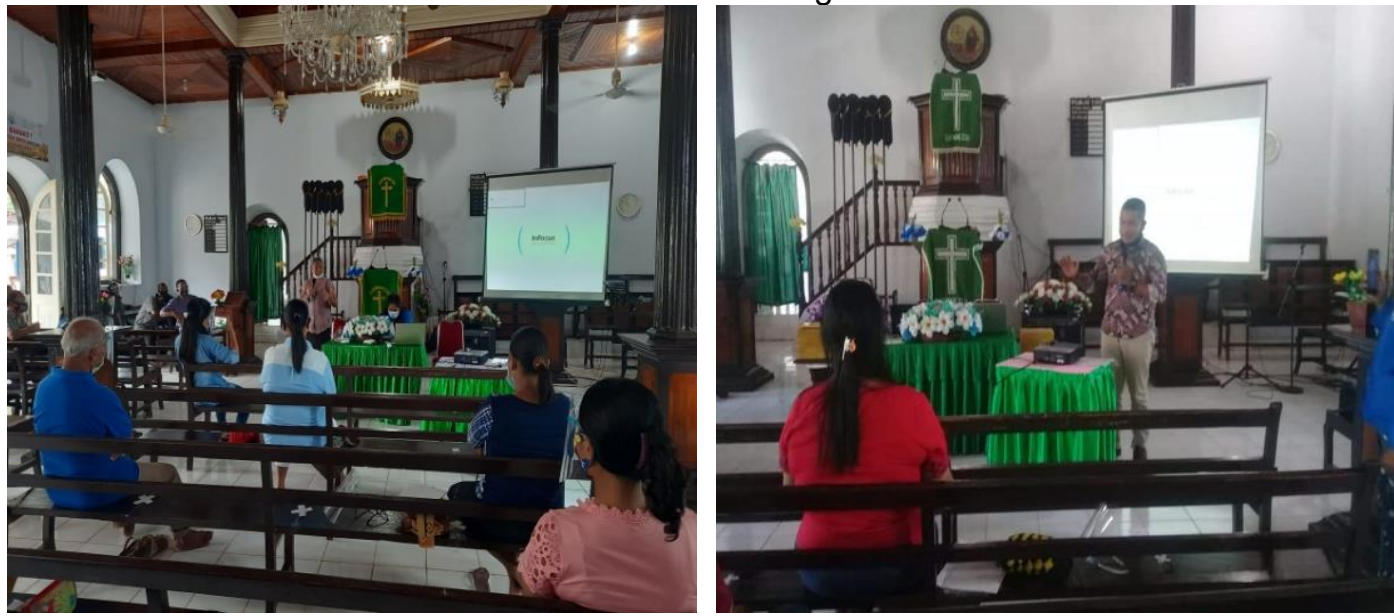

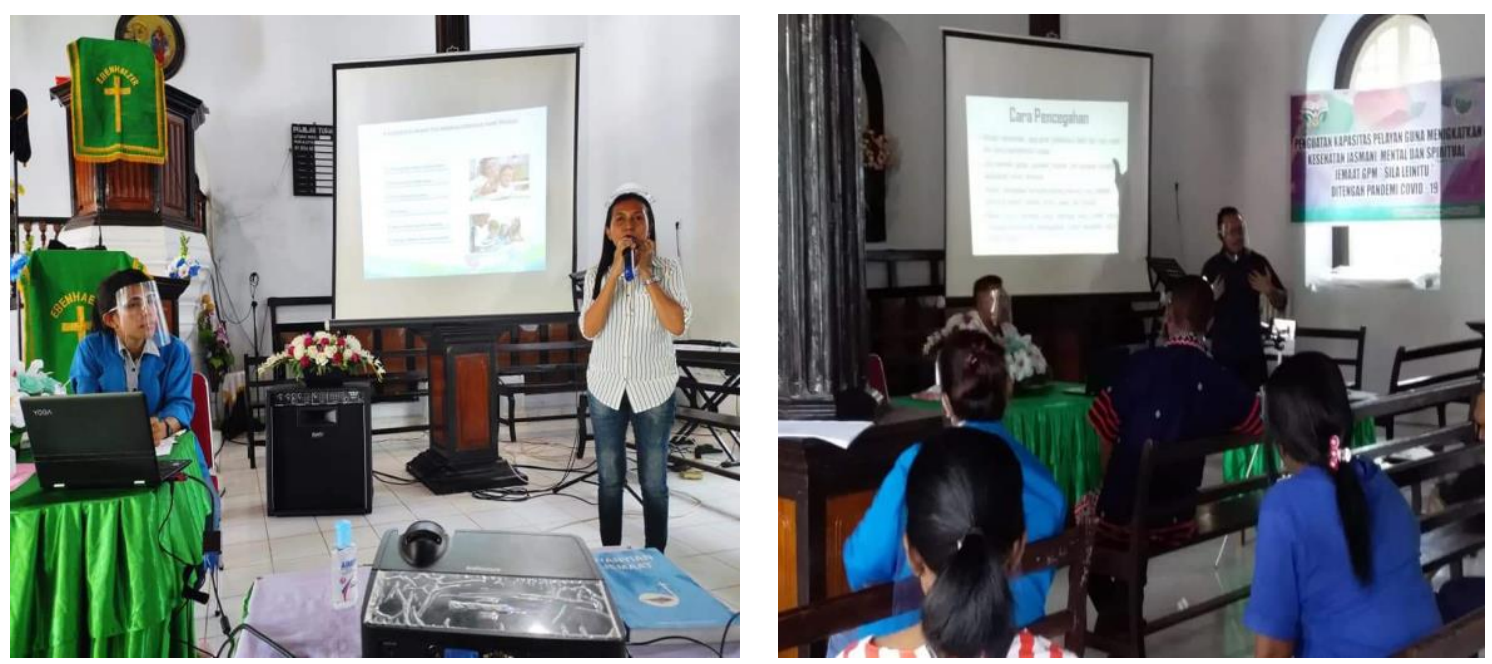

Gambar 3. Gambaran Kegiatan Pengabdian

\subsection{Materi}

1) Materi Sosialisasi Penerapan Protokol Kesehatan Dalam Masa Pandemi

Sosialisasi ini disampaikan oleh Ns. Presly G. Siahaya, M.Sc sebagai fasilitator. Sosialisasi ini bertujuan untuk membuka wawasan para peserta kegiatan PkM tentang cara pencegahan penularan virus Corona. Dalam sosialisasi ini dijelaskan tentang apa itu virus Corona, penyebab Covid-19, tanda dan gejala Covid-19, serta pencegahan Covid-19 (Menteri Kesehatan Republik Indonesia, 2020). Dalam sosialisasi protocol kesehatan ini, tim menyediakan beberapa alat peraga yang dapat digunakan oleh peserta dalam menerapkan protocol kesehatan dalam masa pandemic Covid-19, diantaranya face shield, hand sanitizer, dan ember kran sebagai wadah menampung air untuk mencuci tangan. Tujuan pengadaan alat peraga kesahatan agar masyarakat secara khusus peserta kegiatan benar-benar mengetahui dan memahami pentingnya menjaga kesehatan baik pribadi, keluarga dan lingkungan masyarakat selama masa pandemic Covid-19. Selain itu, tujuan pengadaan alat peraga berupa peralatan kesehatan ini bertujuan untuk memberikan pemahaman kepada masyarakat bahwa virus Covid-19 merupakan wabah penyakit yang serius untuk samasama dihadapi dengan bergandengan tangan. Masyarakat tidak boleh menganggap remeh pandemic Covid-19 yang sedang terjadi, sekalipun daerah Sila-Leinitu merupakan daerah hijau. Pengadaan peralatan kesehatan ini juga bertujuan agar masyarakat selalu waspada dan siap sedia bahwa kapan saja wabah Covid-19 bisa saja menyerang mereka.

2) Materi Sosialisasi Smart Parenting Dalam Masa Pandemi Covid-19

Dalam masa pandemic Covid-19, seluruh aktivitas dialihkan ke rumah. Salah satu aktivitas rutin yang pelaksanaanya dialihkan ke rumah yang proses belajar mengajar. Oleh sebab itu, orangtua perlu dibekali dengan pengetahuan yang mumpuni sehingga mampu menjalankan tugas dan fungsi guru dirumah, yakni membimbing anak dalam menyelesaikan studi dari rumah. Mengingat hal ini menjadi kebutuhan dasar, maka materi sosialisasi smart parenting menjadi hal yang sangat penting untuk disampaikan dalam kegiatan PkM ini. Materi ini disampaikan oleh Ibu Agnes N. Mahakena, M.Si sebagai fasilitator. materi ini sangat penting secara khusus dalam masa pandemic Covid-19. Melalui materi ini diharapkan peserta mampu menerapkan pola pengasuhan yang baik dan benar didalam keluarga selama masa pandemic. Materi sosialisasi yang disampaikan oleh fasilitator ini berbicara tentang bagaimana orangtua menerapkan pola pengasuhan dalam kehidupan keluarga selama masa pandemic Covid-19. Dijelaskan oleh fasilitator bahwa secara teoritis terdapat empat macam pola pengasuhan yakni otoriter, demokratis, pemanjaan, dan penelantaranan (Adawiah, 2017). Fasilitator menjelaskan empat pola pengasuhan ini disertai dengan dampak positif dan negatifnya pada anak. Dijelaskan bahwa pada masing-masing pola asuh 
memiliki kekuatan dan kelemahan, oleh sebab itu orangtua hendaknya memperhatikan sisi positif dan negative dengan baik dan benar agar tepat dalam menerapkan pola asuh. Hal ini disebabkan karena hasil dari tiap pola pengasuhan yang diterapkan akan berdampak bagi perkembangan anak, terutama kepribadian dan perilaku anak.

3) Materi Sosialisasi Layanan Pastoral Konseling Dalam Masa Pandemi Covid-19

Selama virus Corona menjadi sebuah pandemic, masyarakat dianjurkan untuk melakukan aktivitas dari rumah dan mengurangi untuk keluar rumah. Hal ini juga dialami oleh masyarakat Desa Sila dan Leinitu dimana aktivitas masyarakat diluar rumah dikurangi. Salah satu aktivitas yang juga mengalami pembatasan yakni peribadatan dan pelayanan kepada umat. Hal ini menyebabkan ada banyak masalah-masalah yang terjadi dalam kehidupan keluarga, yang tidak disentuh oleh para pelayan. Sehingga dianggap perlu dan menjadi prioritas utama penguatan kapasitas pelayan dalam hal layanan pastoral konseling. Dengan adanya penguatan kapasitas ini, para pelayan dibekali dengan teknik-teknik layanan pastoral konseling ketika terjadi masalah ditengah-tengah kehidupan umat. Selain itu, para pelayan dibekali dengan pemahan yang memadai tentang pentingnya layanan konseling ditengah situasi pandemic, dimana layanan konseling menjadi sangat penting ditengah siatuasi yang penuh dengan persoalan ini. Sosialisasi layanan pastoral konseling dalam masa pandemic Covid-19 ini dismapaikan oleh Ibu L. L. Ririhena, M.Si. Dalam penyampaian materinya, fasilitator menegaskan bahwa dalam masa pandemic Covid-19 ini, para pelayan hendaknya menjadi penolong yang setia bagi umat. Hal ini disebabkan karena dalam masa pandemic, ada banyak persoalan-persoalan yang terjadi dalam kehidupan keluarga, yang membutuhkan bantuan konselor. Dan dalam hal ini yang menjadi konselor adalah para pelayan, baik itu majelis jemaat maupun badan koordinator pelayanan (Bakopel).

4) Materi Sosialisasi Manajeman Stress Dalam Masa Pandemi Covid-19

Salah satu masalah yang paling banyak terjadi dalam masa pandemic Covid-19 yakni persoalah stress atau yang lebih sederhana dikenal dengan istilah kecemasan. Materi ini disampaikan oleh Bpk. Andris Noya, M.Si sebagai fasilitator. Kecemasan dialami oleh semua orang yang mendengar bahkan mengalami gangguan Covid-19. Termasuk juga masyarakat dan jemaat GPM Silaleinitu. Oleh sebab itu, materi tentang bagaimana mengelola stress dalam masa pandemic menjadi salah satu materi yang penting untuk disampaikan. Munculnya stres juga dapat terjadi karena pikiran atau situasi yang membuat seseorang merasa dirinya putus asa, marah, atau bersemangat. Rasa stres dapat memicu respons dari tubuh manusia. Jika tidak tertangani dengan baik, stres dapat menyebabkan gangguan fisik maupun psikologis (gangguan panik, gangguan kecemasan, hingga dapat mengarah ke depresi). Dijelaskan bahwa penyebab stres adalah kondisi pandemi yang mengharuskan masyarakat membatasi aktivitasnya dengan hanya di rumah saja selama berbulan-bulan seringkali menjadi pemicu utama. Faktor lainnya yang juga membuat kondisi stres semakin parah bagi sebagian besar orang, antara lain: masalah ekonomi, adanya penurunan pendapatan atau pemutusan hubungan kerja (PHK), interaksi sosial yang sangat dibatasi atau sangat berkurang, Work From Home yang ternyata lebih menyita waktu, kecemasan berlebihan akan tertular Covid-19 dan ketidakpastian berakhirnya pandemi, yang seringkali disertai adanya gangguan kepribadian. Dalam penyampaian materi, fasilitator mengajak peserta kegiatan untuk mengenal dan mengetahui apa itu stress dan gejala-gejala yang muncul saat seseorang mengalami stress. Dalam proses penyampaian materi, terlihat jelas bahwa materi ini merupakan materi yang baru bagi peserta kegiatan, dimana sebelumnya mereka sama sekali tidak memiliki pemahaman tentang cara mengelaola stress dalam masa pandemic Covid-19. Hal ini terlihat jelas dari pertanyaanpertanyaan pembuka yang disampaikan oleh fasilitator kepada peserta kegiatan tentang "apa itu tress". Kebanyakan peserta belum mampu memberikan definisi yang tepat tentang stress dan gejala-gejala yang muncul sebagai akibat ketika seseorang mengalami stress.

5) Pelatihan Teknik-Teknik Konseling

Setelah proses sosilisasi dilakukan pada kegiatan tahap I, maka dalam tahap II kegiatan PkM diboboti dengan berbagai macam pelatihan untuk menunjang keterampilan pelayan dalam menatalayani umat pada masa pandemic Covid-19. Kegiatan PkM tahap II dibuka 
dengan pelatihan teknik-teknik konseling. Pelatihan ini bertujuan untuk mengasah kemampuan para pelayan dalam menangani setiap masalah yang terjadi ditengah-tengah kehidupan jemaat. Pelatihan teknik-teknik konseling ini dipandu oleh lbu Lolita L. Ririhena, M.Si sebagai fasilitator. Dalam pelatihan ini salah satu teknik konseling yang diajarkan kepada para peserta yakni latihan untuk memiliki kemampuan untuk mendengar dan menganalisa kasus dengan baik dan benar. Mendahului kegiatan pelatihan, fasilitator menyatakan bahwa mendengar adalah kegiatan yang dinamis, yaitu proses mendengar secara aktif percakapan dengan konseli yang dituntut adanya konsentrasi secara penuh. Mendengar aktif untuk memahami isi pembicaraan dan perasaan dari konseli. Tanpa memiliki keterampilan mendengar yang baik, tujuan yang diharapkan dari sebuah proses konseling tidak akan berhasil. Keterampilan mendengar adalah keterampilan yang mendasari keterampilan konselor lainnya yaitu refleksi isi konseling dan perasaan konseli, bertanya, menyimpulkan dan membingkai ulang isi dari pembicaraan konseling. Ketrampilan mendengar bukanlah satu hal yang datang begitu saja. Ketrampilan mendengar bisa dimulai dengan mau mendengar. Kemampuan mendengar perlu dilatih dan dikembangkan.

6) Pelatihan Terapi Relaksasi Otot Progresif

Kecemasan dan stress merupakan dampak yang paling besar diakbatkan karena pandemic Covid-19. Kecemasan dialami oleh sabagian besar masyarakat, termasuk yang ada di Desa Sila dan Leinitu. Setelah melakukan sosialisasi tentang kemampuan individu dalam mengelola stress, Bpk. Andris Noya, M.Si selaku fasilitator membawakan salah satu teknik dalam mengurangi kecemasan pada masa pandemic yakni terapi relaksasi otot progresif. Sebelum melakukan terapi relaksasi, fasilitator memberikan penjelasan secara detail tentang apa itu terapi relaksasi. Fasilitator menjelaskan bahwa terapi relaksasi otot progresif (progressive muscle relaxation) merupakan suatu teknik relaksasi yang menggunakan serangkaian gerakan tubuh yang bertujuan untuk melemaskan dan memberi efek nyaman pada seluruh tubuh. Relaksasi progresif dipandang cukup praktis dan ekonomis karena tidak memerlukan imajinasi yang rumit, tidak ada efek samping, mudah dilakukan, serta dapat membuat tubuh dan pikiran menjadi tenang, rileks dan lebih mudah untuk tidur.

Setelah fasilitator memberikan penjelasan, fasilitator mengarahkan masing-masing peserta untuk berada dalam kondisi relaks dan membuat tubuh senyaman mungkin. Untuk mendapatkan kondisi relaks, maka tiap peserta dianjurkan untuk mengambil posisi duduk yang nyaman. Karena terapi ini dilakukan di dalam gedung gereja, maka peserta diminta untuk mengambil posisi duduk yang nyaman. Sebenarnya terapi ini lebih baik/cocok dilakukan diruangan tertutup tanpa kursi/berbaring sehingga peserta benar-benar merasakan kondisi relaks. Setelah masing-masing peserta telah mengambil posisi duduk yang nyaman, fasilitator memulai terapi ini dengan memutarkan instrument pengantar yang nyaman didengar saat proses terapi berlangsung.

Terapi ini dimulai dengan instruksi yang diberikan oleh fasilitator untuk masing-masing peserta menarik nafas yang dalam. Tarikan nafas diambil dari bagian perut, ditahan beberapa detik, setelah itu dihembuskan perlahan-lahan dari hidung. Kegiatan ini diulang sampai beberapa kali, sampai fasilitator melihat peserta telah benar-benar relaks. Setelah itu fasilitator mengarahkan peserta untuk pusatkan perhatian pada penegangan dan kemudian peregangan otot-otot dalam tubuh. Salah satu metodenya adalah memulai dengan menegangkan otot-otot pada jari kaki anda, kemudian secara progresif bergerak keatas sampai dengan leher dan kepala anda. Dalam proses terapi, fasilitator akan mengarahkan peserta untuk berada dalam sebuah visualisasi. Bayangkan gambar-gambar yang mendamaikan pikiran untuk membawa pikiran peserta ke sebuah tempat yang damai dan tenang. Akan lebih baik jika peserta menutup mata, duduk di sebuah tempat yang sepi dan mengenakan pakaian yang agak longgar. Proses ini dilakukan sampai seluruh anggota tubuh peserta dirasa benar-benar sudah relaks. Proses terapi diakhir dengan penjelasan yang diberikan oleh fasilitator terkait manfaat yang diperoleh peserta ketika melakukan terapi relaksasi. Dijelaskan bahwa manfaat terapi relaksasi mencakup beberapa hal, yakni: menurunkan tekanan darah, meningkatkan aliran darah ke otot-otot besar, mengurangi ketegangan otot dan rasa nyeri kronis, meningkatkan konsentrasi, mengurangi amarah dan 
frustrasi, serta meningkatkan kepercayaan diri untuk menangani masalah (Ulya \& Faidah, 2017).

\section{7) Materi Evaluasi smart parenting}

Evaluasi smart parenting merupakan sesi yang diadakan untuk mengevaluasi apakah pola asuh yang diterapkan di rumah oleh orangtua telah berjalan dengan baik sesuai dengan apa yang telah dijelaskan dalam materi smart parenting pada tahap I. Sesi ini dipandu oleh lbu Agnes N. Mahakena, M.Si sebagai fasilitator. Untuk mengevaluasi efektivitas pola pengasuhan orangtua di rumah selama masa pandemic Covid-19, fasilitator menyusun angket sederhana sebagai panduan diskusi. Angket tersebut berisi pernyataan-pernyataan tentang empat pola asuh yang telah dijelaskan sebelumnya kepada peserta dalam kegiatan PkM tahap I. Peserta diminta tanggapannya terkait dengan setiap pernyataan yang dibacakan oleh fasilitator. Selain menjawab setuju atau tidak setuju, peserta juga diminta untuk memberikan penjelasan atas jawaban tersebut. Sesi evaluasi smart parenting yang dilakukan ini memperoleh tanggapan serius dari peserta dengan berbagai tanggapantanggapan baik berupa pertanyaan maupun masukan.

\subsection{Masyarakat Sasaran}

Kegiatan ini ditujukan kepada perangkat pelayan di Jemaat GPM Sila-Leinitu, Kecamatan Nusalaut, Kabupaten Maluku Tengah, Maluku. Perangkat pelayan terdiri Pendeta, Majelis Jemaat, serta Badan Koordinator Pelayanan (Bakopel) pada masing-masing unit pelayanan.

\section{Tinjauan Hasil Yang Dicapai}

Kegiatan pengabdian yang dilaksanakan di Jemaat GPM Sila-Leinitu, Kecamatan Nusalaut, Kabupaten Maluku Tengah berlangsung sesuai dengan yang telah direncanakan oleh tim. Kegiatan berlangsung dengan baik dan mendapat respon positif dari para peserta kegiatan. Respon positif terlihat dari antusias kehadiran peserta yang tetap stabil dalam pelaksanaan kegiatan dalam dua tahap ini. Selain itu, tim juga menyebarkan lembar evaluasi kegiatan untuk memperoleh tanggapan balik dari peserta terkait efektivitas kegiatan. Sebaik besar peserta kegiatan memberikan tanggapan positif dalam lembar evaluasi kegiatan. Selain itu peserta juga mengharapkan agar kegiatan serupa tidak hanya berlangsug satu kali tapi dapat diulang lagi beberapa kali untuk memperlengkapi para pelayan yang tidak berkesempatan untuk hadir dalam kegiatan kali ini karena jumlah peserta yang dibatasi akibat pandemic Covid-19. Hasil kegiatan juga terlihat dari kegiatan praktek teknik konseling yang berjalan dengan baik, dimana peserta dapat mempraktekkan teori yang diperoleh dari fasilitator pada tahap I tentang teknik-tekinik konseling. Dalam sesi praktek (Tahap II) setiap peserta diberikan kesempatan untuk melakukan praktek konseling kepada sesama peserta. Lebih dari itu, beberapa peserta juga berhasil mempraktekan teknik relaksasi otot progresif, dimana peserta diberikan kesempatan untuk memandu proses relaksasi berdasarkan pedoman relaksasi yang telah diberikan oleh fasilitator. Dengan demikian dapat disimpulkan bahwa kegiatan ini berjalan dengan baik.

Sehingga dapat disimpulkan adanya peningkatan pengetahuan dan keterampilan para pelayan tentang teknik-teknik konseling, penerapan pola pengasuhan yang baik dalam masa pandemic, serta penerapan teknik relaksasi otot progresif.

\section{Daftar Pustaka}

Adawiah, R. (2017). Pola Asuh Orang Tua Dan Implikasinya Terhadap Pendidikan Anak (Studi Pada Masyarakat Dayak di Kecamatan Halong Kabupaten Balangan). Jurnal Pendidikan Kewarganegaraan, $7(1), 33-48$.

Buana, R. D. (2020). Analisis Perilaku Masyarakat Indonesia dalam Menghadapi Pandemi Covid-19 dan Kiat Menjaga Kesejahteraan Jiwa. Sosial Dan Budaya, Fakultas Syariah Dan Hukum Universitas Islam Negeri (UIN) Syarif Hidayatullah Jakarta, 53(9), 1689-1699. Retrieved from file:///C:/Users/User/Downloads/fvm939e.pdf

Dwiraharjo, S. (2020). Konstruksi Teologis Gereja Digital: Sebuah Refleksi Biblis Ibadah Online di Masa Pandemi Covid-19. EPIGRAPHE: Jurnal Teologi Dan Pelayanan Kristiani, 4(1), 1. 
https://doi.org/10.33991/epigraphe.v4i1.145

Menteri Kesehatan Republik Indonesia. (2020). Permenkes RI KMK No. HK.01.07/MENKES/382/2020. Peraturan Menteri Kesehatan Republik Indonesia, Nomor 9(Pedoman Pembatasan Sosial Berskala Besar dalam Rangka Percepatan Penanganan Corona Virus DIsease 2019 (COVID-19)), 1-66. Retrieved from http://jurnalrespirologi.org/index.php/jri/article/view/101

Nasruddin, R., \& Haq, I. (2020). Pembatasan Sosial Berskala Besar ( PSBB ) dan Masyarakat Berpenghasilan Rendah. Salam: Jurnal Sosial \& Budaya Syar-I, 7(7), 639-648. https://doi.org/10.15408/sjsbs.v7i7.15569

Siahaan, M. (2020). Dampak Pandemi Covid-19 Terhadap Dunia Pendidikan. Jurnal Kajian IImiah, 1(1), 73-80. https://doi.org/10.31599/jki.v1i1.265

Ulya, Z. I., \& Faidah, N. (2017). PENGARUH TERAPI RELAKSASI OTOT PROGRESIF TERHADAP PENURUNAN TEKANAN DARAH PADA PENDERITA HIPERTENSI DI DESA KORIPANDRIYO KECAMATAN GABUS KABUPATEN PATI. Journal of Chemical Information and Modeling, 6(2), 1-9. 